\title{
Dynamics of Haematobia irritans irritans (Diptera: Muscidae) Infestation on Nelore Cattle in the Pantanal, Brazil
}

\author{
Antonio Thadeu M Barros
}

Embrapa Pantanal, Rua 21 de Setembro 1880, 79320-900 Corumbá, MS, Brasil

From June 1993 to May 1995, horn fly counts were conducted twice a month on untreated Nelore cattle raised extensively in the Pantanal. Horn fly population showed a bimodal fluctuation and peaks were observed every year after the beginning (November/December) and at the end (May/June) of the rainy season, which coincided with mid-late spring and mid-late fall, respectively. Horn flies were present on cattle throughout the year in at least $64 \%$ of the animals. Mean horn fly numbers on animals did not exceed 85 flies/cow during peaks and were under 35 flies/cow in most of the remaining periods. The highest infestations (population peaks) were short and dropped suddenly within two weeks. Less than $15 \%$ of the animals in both herds could be considered as "fly-susceptible" - showing consistently higher infestations, or "fly-resistant" - showing consistently lower infestations.

Key words: horn fly - seasonality - ecology - Pantanal - Brazil

The horn fly (Haematobia irritans irritans) is considered an important economic pest in several countries due to significant losses in cattle production. Economic losses were estimated in \$ 876 million in the United States (Kunz et al. 1991). This livestock pest was first recorded in the north of Brazil during the early 1980's (Valério \& Guimarães 1983), and after 1984 it quickly spread throughout the country. The Pantanal, a large seasonal floodplain located in the center of South America, has around 3.8 million cattle (Cadavid Garcia 1986) and is considered one of the most important beef cattle raising areas in Brazil. In 1991, the horn fly entered this region, causing a widespread concern among cattle producers (Barros 1992). Few studies on the dynamics of horn fly populations have been conducted in Brazil (Collares 1990, Saueressig 1993, Alves-Branco et al. 1997, Bianchin \& Alves 1997, Lima et al. 1999), none in this region. The main purpose of the present study was to determine horn fly seasonality and to provide basic information on infestation on Nelore cattle in the Pantanal; such information will help horn fly control in the region.

\section{MATERIALS AND METHODS}

The study was conducted from June 1993 to May 1995 at the Nhumirim ranch $\left(18^{\circ} 59^{\prime} \mathrm{S}\right.$,

Fax: +55-67-2311011. E-mail: thadeu@cpap.embrapa.br Received 19 May 2000

Accepted 20 December 2000 $\left.56^{\circ} 39^{\prime} \mathrm{W}\right)$, an experimental station of the Embrapa Pantanal located in the Nhecolândia subregion, about $150 \mathrm{~km}$ east from the city of Corumbá, State of Mato Grosso do Sul, Brazil. This subregion has an altitude around $100 \mathrm{~m}$ above sea level and consists of a mosaic of lakes, grassland, savanna ("cerrado" vegetation) and dense savanna ("cerradão" vegetation). The climate is the "Savanna subtype (AW) of the Tropical Rain Climate (A)" with an annual rainfall of about $1,246 \mathrm{~mm}$ (Ratter et al. 1988). The Nhumirim ranch has about 4,374 ha and maintain extensively more than 1,000 cattle, mostly Nelore. No insecticide treatment was applied on animals since spring of 1992, when a pyrethroid pour-on was used.

At the beginning of the study, 4 to 16 year-old Nelore cows ( $80 \%$ from 4 to 9 years old) were distributed in two herds with 60 (herd A) and 40 animals (herd B), which were maintained extensively in separate native grass pastures, approximately 4 $\mathrm{km}$ apart. The initial protocol of this study included a treated group, which would be treated when fly numbers reached 200/animal, and a control group. However, because infestations were always below threshold level, both herds were left untreated.

Horn fly counts on each herd were carried out twice per month, in consecutive weeks. Unless climatic conditions did not permit, fly counts at both herds were conducted in consecutive days. Between 6:30 and 9:30 a.m., two observers riding horses counted flies in a minimum of $50 \%$ of the grazing animals randomly selected from each herd. Fly counts were conducted at a close range and a pair of binoculars were used when necessary. 
Individual variation of fly numbers (as an indicator of host resistance) was approached in two ways. The first was based on the mean number of flies in each count; animals with a "high infestation" had at least twice the herd mean number of flies and those with a "low infestation" had half the mean number or less. The frequency of each animal regarding its infestation level was calculated. The second approach took into account the distribution pattern of fly infestation among animals (Steelman et al. 1993). For each count, cows were distributed in quartiles according to their level of infestation. At the end of the study, cows were classified as either fly-susceptible or fly-resistant when their frequency in the upper and lower quartile was $>50 \%$, respectively.

Meteorological parameters such as temperature, relative humidity and rainfall were obtained from a meteorological station located in the ranch. Correlation analyses between fly counting data and climatic parameters for the previous one to four weeks prior to each count were performed by using the procedure CORR of the SAS software (SAS Institute 1989).

\section{RESULTS}

In general, meteorological patterns can be considered typical for the region (Fig. 1). Mean monthly temperatures ranged from 19.5 to $28.4^{\circ} \mathrm{C}$ (averaged $25.1^{\circ} \mathrm{C}$ ); temperatures were higher in the October-March period and lower in June-August. Mean relative humidity ranged from 66.9 to $86.4 \%$ (averaged 79.2\%), with records $\geq 80 \%$ from December to June and lowest records in September. The first year was drier than usual and cumulative rainfall was $806.5 \mathrm{~mm}$; the second year was more typical, with $1,262.5 \mathrm{~mm}$ rainfall. Precipitation occurred most from October to April and was scarce from July to September.

Fluctuation of the fly population showed a similar trend in both herds (Fig. 2). In the first year of study (June/1993-May/1994), a single isolated peak of flies was observed by the end of November, with 75 (5-325) and 77 (10-275) flies/cow observed for herds $\mathrm{A}$ and $\mathrm{B}$, respectively. In the remaining counts, fly numbers did not exceed 31 flies/cow during this year. Mean infestations were generally higher during the 2nd year (June/1994-May/1995) and peaks were recorded in June, November, and
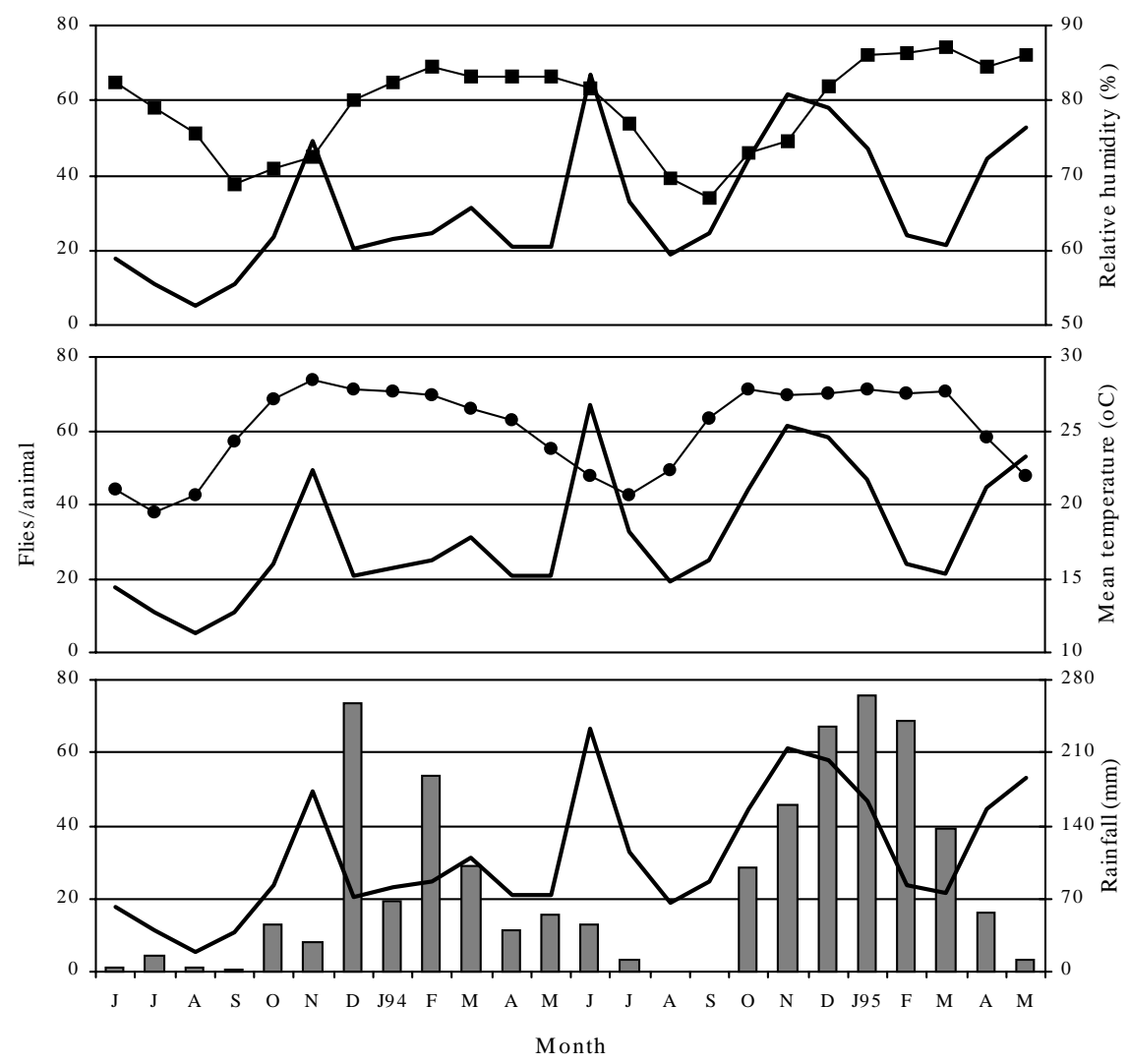

Fig. 1: dynamics of horn fly infestation on Nelore cattle (-) in relation to climatic parameters in the Pantanal, Brazil, from June 1993 to May 1995. 
May (Fig. 2). Number of flies per animal during peaks averaged 80 (10-325), 82 (60-150), and 60 (15-153) for herd A, and 89 (15-250), 71 (60-100), and 64 (10-155) for herd B, respectively. A relatively higher number of flies, ranging from 40 to $50 /$ cow, was observed in the counts near these population peaks. Lower mean number of flies, generally under 35 flies/cow, was observed during the wet (January/March) and dry (July/September) periods. In general, a high percentage of animals with infestation under 40 flies/cow was observed, except near population peaks (Fig. 3).

Poor correlation (Pearson coefficients ranging 0.01-0.40) was found between fly numbers and climatic parameters for the whole study period. In addition, no consistent correlation was observed between fly numbers and time prior to counting. Al- though variable, higher correlation was found when data were analyzed by periods, taking into account natural population tendencies, such as increase and decline (Table). In general, population increase observed in spring (August-November) was best explained by mean temperature from the previous $1 \mathrm{st}$ and 3rd weeks prior counting (WPC) $(\mathrm{r}=0.82 ; \mathrm{p}<$ 0.05 ) and accumulated rainfall from the previous 3 WPC $(r=0.84, p<0.01)$. Reduction of fly population observed in late spring/summer (NovemberFebruary) was most associated with relative humidity from the 2 WPC $(r=-0.82, p<0.05)$, while population decline in winter (June-August) was highly associated with temperature from the previous 4 WPC $(r=0.93, p<0.01)$ and relative humidity from the 3 WPC $(r=0.99 ; p<0.01)$.

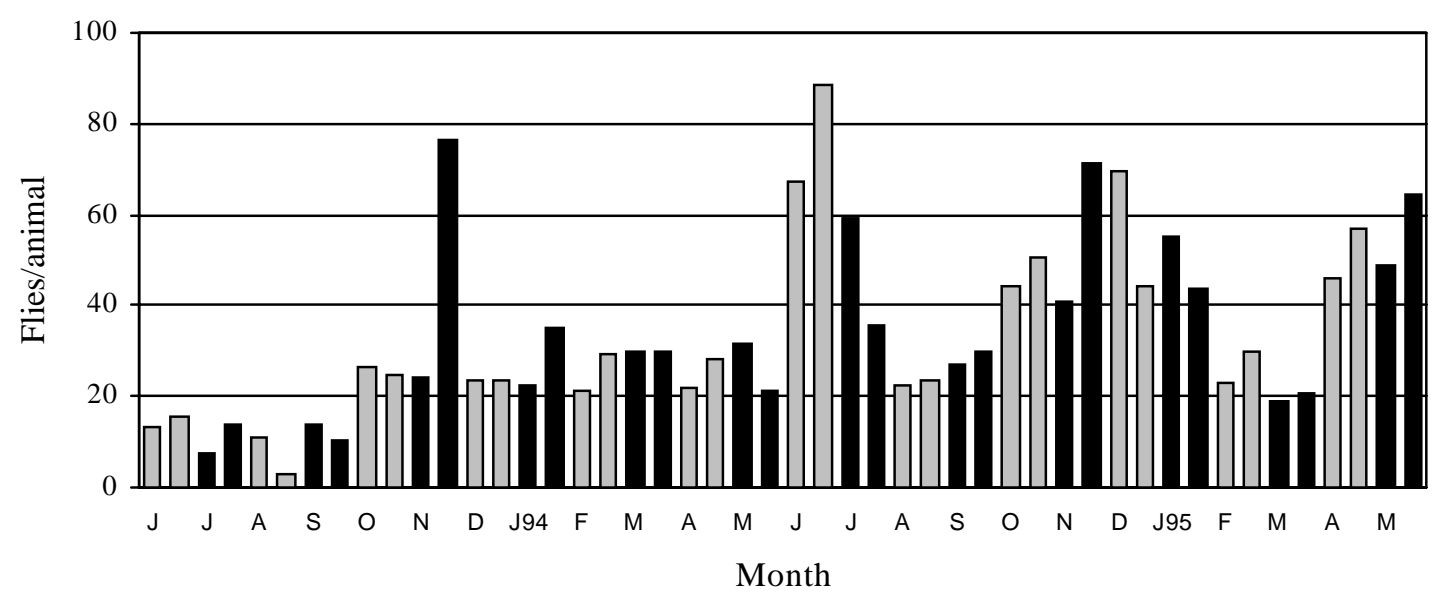

Fig. 2: mean number of horn flies/cow in untreated Nelore herds in the Pantanal, Brazil, from June 1993 to May 1995. Bar patterns represent biweekly counts per month.
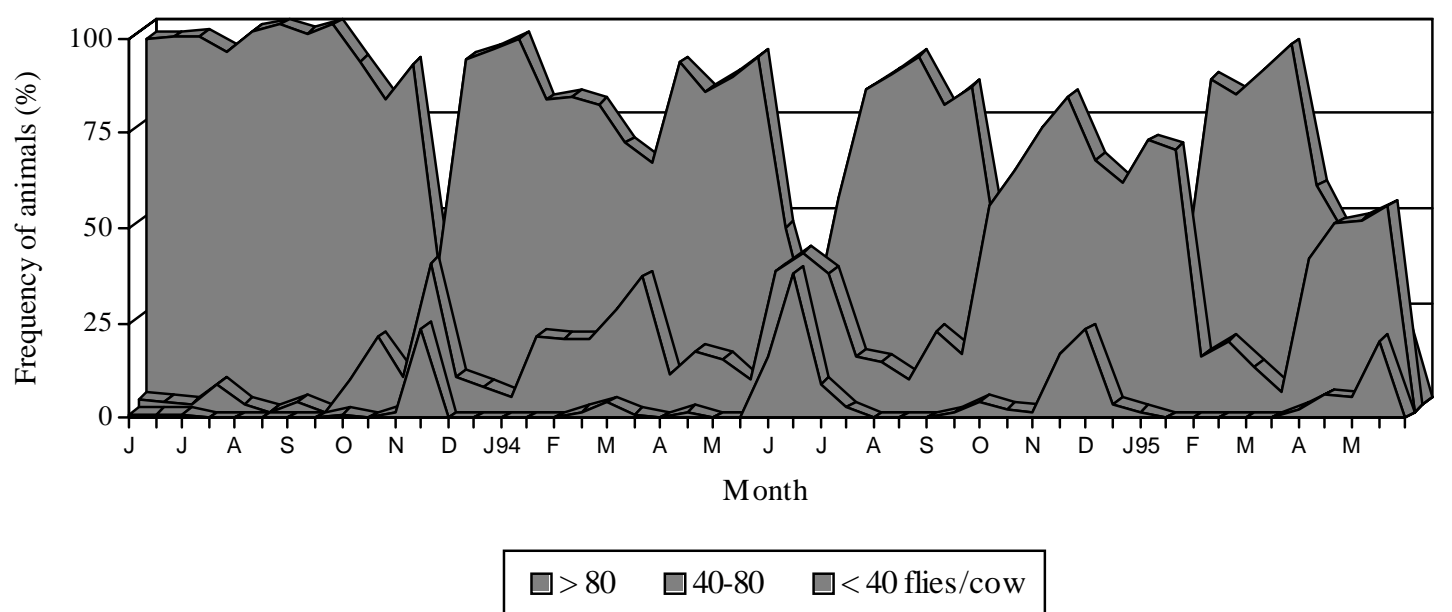

Fig. 3: seasonal frequency of untreated Nelore cows related to horn fly infestations in the Pantanal, Brazil, from June 1993 to May 1995 
TABLE

Highest statistically significant correlation coefficients (r) between horn fly numbers on untreated Nelore cows and climatic parameters from the previous one to four weeks, in the Pantanal, Brazil

\begin{tabular}{llll}
\hline Population tendency (period) & $\begin{array}{l}\text { Mean } \\
\text { temperature }\end{array}$ & $\begin{array}{l}\text { Relative } \\
\text { humidity }\end{array}$ & $\begin{array}{l}\text { Accumulated } \\
\text { rainfall }\end{array}$ \\
\hline Declining (Jun.-Aug. 1993) & $0.93^{a}(4)$ & $0.99^{a}(3)$ & $\mathrm{ns}$ \\
Increasing (Aug.-Nov. 1993) & $\mathrm{ns}$ & $\mathrm{ns}$ & $\mathrm{ns}$ \\
Declining (Nov.-Dec. 1993) & - & - & - \\
Fluctuating (Dec. 1993-May 1994) & $\mathrm{ns}$ & $\mathrm{ns}$ & $0.59^{b}(3)$ \\
Increasing (May-Jun. 1994) & $\mathrm{ns}$ & $\mathrm{ns}$ & $\mathrm{ns}^{b}$ \\
Declining (Jun.-Aug. 1994) & $\mathrm{ns}$ & $0.98^{b}(1)$ & $0.97^{b}(4)$ \\
Increasing (Aug.-Nov. 1994) & $0.82^{b}(1,3)$ & $\mathrm{ns}$ & $0.84^{a}(3)$ \\
Declining (Nov. 1994-Feb. 1995) & $\mathrm{ns}$ & $-0.82^{b}(2)$ & $\mathrm{ns}$ \\
Fluctuating (Feb.-Mar. 1995) & - & - & - \\
Increasing (Mar.-May 1995) & $-0.93^{a}(2)$ & $\mathrm{ns}$ & $-0.97^{a}(4)$ \\
\hline
\end{tabular}

ns: non-significant ( $\mathrm{p}>0.05)$; values in parenthesis represent the number of weeks prior to fly counting; $a$ : $\mathrm{p}<0.01$; $b: \mathrm{p}<0.05$

Fly numbers declined generally within a 2 -week period following fly peaks, evidencing a short length of the highest infestations (Fig. 2). Except during population peaks, when fly numbers increased suddenly, the number of flies in consecutive counts showed little variation throughout the study. Horn flies were observed in all counts and were present on at least $68 \%$ and $64 \%$ of the animals from herds A and B, respectively. Furthermore, flies were recorded in all animals in $72.9 \%$ and $91.7 \%$ of the counts carried on herds A and B, respectively.

A low number of animals showed consistently higher infestations (twice the herd average) than the rest of the herd in most counts. Only 6\% (herd A) and $7.5 \%$ (herd B) of the animals showed high infestations in at least $15 \%$ of the counts, and no animal showed such infestation in more than $37 \%$ of the counts. On the other hand, $65 \%$ of the animals from both herds showed high infestations in a few counts (5\% or less). Also $15 \%$ and $35 \%$ of the animals from herds A and B, respectively, did not show such infestation in any count. Low infestations (half the herd average) were observed in 40 and $55 \%$ of the animals in a maximum of $20 \%$ of the counts from herds $\mathrm{A}$ and $\mathrm{B}$, respectively. However, only $13.3 \%$ (herd A) and 10\% (herd B) of the animals had low infestations in more than $40 \%$ of the counts, and no animal showed such infestation in more than $60 \%$ of the counts.

Individual variation among animals was similar for both herds. Fly-susceptible cows represented $13.3 \%$ and $15 \%$ of herds $\mathrm{A}$ and $\mathrm{B}$, respectively. On the other hand, $13.3 \%$ and $12.5 \%$ of the cows were classified as fly-resistant, respectively. Mean number of flies was 2.3 and 2.2 times higher in the fly-susceptible cows than in cows from the fly-resistant group in herds A and B, respectively.

\section{DISCUSSION}

Horn fly populations peaked in the Pantanal after the beginning (November/ December) and near the end (May/June) of the rainy season. A similar trend was observed in Roraima (Collares 1990). In Planaltina, DF, higher infestations were recorded in March or May (depending on the year) and in September/October (Saueressig 1993). In Araçatuba, SP, Lima et al. (1999) recorded a maximum number of flies in October as well. In the State of Rio Grande do Sul, population peaks were recorded in March and November (Alves-Branco et al. 1997). This bimodal fluctuation was also observed in central Argentina, where higher infestations were found in mid to late spring and in late summer to mid fall (Guglielmone et al. 1997). Differently from most studies conducted in Brazil, Bianchin and Alves (1997) observed in Campo Grande, MS, a single population peak in February (also related to a reduced rainfall). However, timing and relatively short duration (from late November to late April) of such study may explain differences regarding population peaks.

Despite local peculiarities, horn fly populations seem to follow a general pattern where higher temperatures and moderate rainfall are favorable to horn fly development and eventually determine its population peak if these conditions persist for a certain time.

Generally, lower numbers of flies were observed during the wet (January/March) and dry (July/September) periods. Other authors have observed a similar population dynamics elsewhere in Brazil (Saueressig 1993, Alves-Branco et al. 1997, Lima et al. 1999). These low infestations may be explained by the occurrence of unfavorable meteorological conditions. In the Pantanal, three 
main meteorological factors may have adversely influenced horn fly populations, either concomitantly or at different times: rainfall (excess or absence), seasonal flooding, and lower temperatures (winter). The heavy rainfalls from December to February, which is usually the wettest period of the year in the region, may have caused the disintegration of fresh bovine pats and associated increasing of horn fly larvae mortality (Hughes 1979). Furthermore, due to the relatively high susceptibility of horn fly preimaginal stages to water immersion (Jones \& Kunz 1996), it is probable that seasonal flooding (January to March) could have contributed to reduce the emergence of adult flies. Furthermore, the dry period concomitant to lower temperatures and relatively strong winds occurring during winter could also have contributed to unfavorable conditions for horn fly development. In Argentina, Torres et al. (1992) observed a marked decrease in horn fly numbers due to flooding and pouring rains in the summer.

General patterns of population dynamics were not determined by the same association between climatic factors. Thus, horn fly population can peak following the increase of temperature and rainfall (spring) after a dry and a cold season, or influenced by a reduction in rainfall (fall) after a wet season. On the other hand, despite high temperatures, population decline can occur due to the increase (excessive) of rainfall and humidity (summer), or due to a reduction of temperature and humidity (winter).

The zebu breed (Doube 1984, Steelman et al. 1997) may explain the relatively low number of flies/cow observed in this study (maximum of 84). Low infestations have been found in other parts of the Brazilian mid-west, where zebu cattle have been raised extensively. In Planaltina, average fly numbers did not exceed 70/animal in Simental x Nelore cattle (Saueressig 1993); also, in Campo Grande, mean infestations on Nelore cattle were not greater than 80 flies/animal (Bianchin \& Alves 1997). In São Paulo, Campos Pereira et al. (1992) found a maximum of 42 flies/cow in Nelore cattle during a fall study (March/June).

The frequency of either "fly-resistant" or "susceptible" animals (or animals with either "low" or "high" infestations) is relatively low within a given herd. Although some authors have observed a consistency of individual classification along the study (Steelman et al. 1993, Bianchin \& Alves 1997), individual number of flies can vary greatly among counts and rare animals showed a more consistent tendency of infestation. In fact, individual frequencies along counts were always under $40 \%$ (most below $15 \%$ ) and $60 \%$ (most below $40 \%$ ) for fly- resistant (low infestation) and fly-susceptible (high infestation) animals, respectively. Similarly as observed by Steelman et al. (1993), the mean number of flies on susceptible cows was more than twice the number of flies on resistant animals. The use of a $25 \%$ frequency as a category cutoff, as suggested by these authors, was precluded in the present study because some animals showed such frequency in both susceptible and resistant categories. Discussion about factors affecting individual differences to horn flies is beyond the scope of this study.

Although the relatively low horn fly infestations and short peaks may suggest a minor economic importance of this pest, when compared to studies conducted in other countries, economic thresholds may vary from one place to another and local studies (based on its realistic yield loss, market values, and management costs) are needed to properly assess the economic importance of the horn fly in the region.

\section{ACKNOWLEDGEMENTS}

To Geraldo R do Nascimento, Waldomiro Lima e Silva and Wibert de Avellar for their valuable assistance in field activities and to Valdete dos S Sanchez and Ana Paula K Ismael for laboratorial assistance. To the employees of the Nhumirim ranch for the logistic support.

\section{REFERENCES}

Alves-Branco F de PJ, Pinheiro A da C, Sapper M de FM 1997. Epidemiologia da Haematobia irritans na região da campanha do RS - Dados preliminares. Rev Brasil Parasitol Vet 6 (Suppl. 1): 46.

Barros ATM 1992. Recomendações para controle da mosca-dos-chifres no Pantanal, Corumbá, MS, Embrapa CPAP, Comunicado Técnico 10, 4 pp.

Bianchin I, Alves RG de O 1997. Mosca-dos-chifres: comportamento e danos em bovinos nelores, Campo Grande, MS, Embrapa CNPGC, Comunicado Técnico 55, 8 pp.

Cadavid Garcia EA 1986. Estudo técnico-econômico da pecuária bovina de corte do Pantanal MatoGrossense, Corumbá, MS, EMBRAPA-CPAP, Documentos 4, 150 pp.

Campos Pereira M, Vieira-Bressan MCR, Cossi Jr O 1992. Field trial to assess the efficacy of insecticides for the control of horn flies on pastured beef cattle in Brazil. Rev Brasil Parasitol Vet 1: 41-43.

Collares NCP 1990. Biologia da Haematobia irritans em Roraima, MSc Thesis, Universidade Federal de Minas Gerais, Belo Horizonte, 67 pp.

Doube BM 1984. The effect of breed and coat colour on numbers of the buffalo fly Haematobia irritans exigua De Meijere, (Diptera, Muscidae) on bovine hosts. J Aust Entomol Soc 23: 39-45.

Guglielmone AA, Anziani OS, Mangold AJ, Giorgi RE, Volpogni MM, Flores SG 1997. Seasonal variation of Haematobia irritans (Diptera: Muscidae) in a recently infested region of central Argentina. Bull Entomol Res 87: 55-59. 
Hughes RD 1979. Rainfall as a cause of mortality in a dung breeding fly. J Aust Entomol Soc 18: 323-327.

Jones SR, Kunz SE 1996. Effects of immersion in water on survival of preimaginal stages of Haematobia irritans (Diptera, Muscidae). J Med Entomol 33: 27 31.

Kunz SE, Murrel KD, Lambert G, James LF, Terrill CE 1991. Estimated losses of livestock to pests. In D Pimentel, CRC Handbook of Pest Management in Agriculture, Vol. I, CRC, Boca Raton, p. 69-98.

Lima LGF, Perri SHV, Prado AP 1999. Comparação de métodos de contagem da mosca dos chifres (Haematobia irritans irritans) por estimativa visual e por filmagem em bovinos da raça Nelore. Seminário Brasileiro de Parasitologia Veterinária, 11, Anais, Salvador, p. 121.

Ratter JA, Pott A, Pott VJ, Cunha CN da, Haridasan M 1988. Observations on woody vegetation types in the Pantanal and at Corumbá, Brazil. Notes RGB Edinburg 45: 503-525.

SAS Institute 1989. SAS/STAT user's guide, version 6, 4th ed., SAS Institute, Cary, NC.
Saueressig TM 1993. Dinâmica populacional da moscados-chifres Haematobia irritans em uma área do Distrito Federal. Congresso Internacional de Medicina Veterinária em Língua Portuguesa, 6, Anais, Salvador, p. 344-345.

Steelman CD, Brown MA, Gbur EE, Tolley G 1997. The effects of hair density of beef cattle on Haematobia irritans horn fly populations. Med Vet Entomol 11: 257-264.

Steelman CD, Gbur EE, Tolley G 1993. Individual variation within breeds of beef cattle in resistance to horn fly (Diptera: Muscidae). J Med Entomol 30: 414420.

Torres PR, Abrahamovich AH, Romano A 1992. Estudio de la eficacia de la Ciflutrina "Pour on" contra Haematobia irritans (L. 1758) (Diptera: Muscidae) en bovinos bajo condiciones de pastoreo en el norte de la provincia de Santa Fe (Argentina). Vet Arg 86: 394-398.

Valério JR, Guimarães JH 1983. Sobre a ocorrência de uma nova praga, Haematobia irritans (L.) (Diptera, Muscidae) no Brasil. Rev Bras Zool 1: 417-418. 